\title{
Political economy of preferential trade agreement: the case of bilateral asymmetric negotiation
}

The purpose of this paper is to analyse the political economy of preferential trade agreements based on a sequential non-cooperative Stackelberg political game between a large economy and a small one, in which the political dispute of rival lobby groups defines the unilateral stance of both governments in the first stage; and the Stackelberg "coalition-proof" equilibrium defines the free trade agreement format in the second stage. Finally, a few modifications in the initial game structure are discussed in order to enhance the small economy's negotiation power. The political economy model is applied to FTAA case.

Key-words: FTAA; political economy; bargaining; non-cooperative games

JEL Classification: F02, F13, F15

\section{INTRODUCTION}

During the last few decades, international trade has been deeply characterised by both multilateral liberalisation agreements and regional negotiations for preferential trade areas implementation such as the European Union, NAFTA and Mercosur. ${ }^{2}$ In particular, since the launch of the "Initiative for the Americas" in 1990, thirty-four countries have been negotiating the creation of the Free Trade Area of Americas (FTAA).

\footnotetext{
${ }^{1}$ Doctor in Economics at IPE-USP and MA in Financial Economics at FGV-EAESP. Professor of Economics at Ibemc-São Paulo and FGV-EAESP (e-mail: motta_daniel@uol.com.br). A previous version of this paper was presented at the First Brazilian Workshop of Game Theory at IPE-USP (2002). I am in debt with Maria Carolina da Silva Leme for her useful and clarifying suggestions. I gratefully acknowledge Arthur Barrionuevo Filho and Fabiana Rocha for their useful comments. As usual I assume full responsibility for any remaining error in this paper. Submitted: July 2004; Accepted: March 2006.
}

${ }^{2}$ See Obstfeld (1998) and Krueger (1999). 
In this context, three main issues have been analysed by the International Trade theory: the welfare effects of regional integration; the relation between multilateral trade liberalisation and regional integration; and, finally, the political economy of preferential trade agreements. ${ }^{3}$ Given the importance of FTAA for Brazilian economy, this paper focuses on the political economy analysis of FTAA based on a sequential political Stackelberg game between the United Sates and Brazil.

According to the political economy analysis, the viability and the form of a preferential trade agreement reflect the relative political power of lobby groups representing industry special interests and also the extent of government's concern for the plight of the average voter. Grossman and Helpman (1994) examine the political economy of protectionist barriers concerning the agent-principal analytical framework developed by Bernhein and Whinston (1986), in which lobby groups offer financial support to incumbent politicians in their home country, but link their contributions to the effective actions decided by the government regarding the protectionist structure. Krueger (1994) argues that the marginal return of financial contributions offered by lobby groups would not be larger than the expected marginal gain associated with the national trade policy adopted by government.

In opposition to traditional benevolent state seeking the aggregate national welfare maximization, Grossman and Helpman (1994) point out that politicians would make protectionist structure for sale by maximizing a weighted sum of aggregate social welfare and total financial contributions offered by lobby groups. In this context, according to Krishna (1998), the national trade policy may be considered as a public good whose benefits are captured by political organized lobby groups.

Finally, Grossman and Helpman (1995) examine the political economy of the bargaining process for the implementation of a preferential trade agreement between two symmetric economies. In the initial stage, both governments would be willing to endorse an agreement calling for complete or partial liberalization of all bilateral trade, depending on the weighted sum of aggregate social welfare and on the total financial contributions offered by lobby groups. In the second stage, the outcome of bilateral negotiation would determine not only the political viability but also the form of the preferential trade agreement.

Specifically, this paper applies the political economy structure of the sequential political game between two symmetric small economies, developed by Grossman and Helpman (1995) in a sequential political non-cooperative game between two

\footnotetext{
${ }^{3}$ Viner (1950), Bhagwati (1971), Dixit and Norman (1980), Krugman (1991) and Krueger (1995) have developed the main theoretical contributions regarding trade and welfare effects of preferential trade agreements. Baldwin and Venables (1995), Ethier (1998) and Freund (2000) analyse the relation between multilateral trade liberalisation and regional trade agreements. For a careful review, see Bhagwati and Panagariya (1996).
} 
asymmetric economies, in which the large economy becomes a Stackelberg leader in the negotiation process for the implementation of a preferential trade agreement.

From all three main issues analysed by the International Trade theory - that is, the welfare effects of regional integration; the relation between multilateral trade liberalisation and regional integration; and, finally, the political economy of preferential trade agreements - this paper focuses on the political economy analysis of FTA based on a sequential political Stackelberg game between a large and a small economies. Eventually, this paper attempts to apply some of the mathematical insights in the analysis of the FTAA.

This paper is organized as follows. Section II presents statistics and stylised facts regarding Free Trade Area of Americas. Based on Grossman and Helpman (1995), Section III and Section IV focus on the development of the analytical framework and the initial stage of the sequential political game, respectively. Section V examines the second stage of the game, developing the Stackelberg noncooperative political game between a large economy and a small one. Section VI analyses the bargaining power of the small economy in two alternative situations: arise of outside opportunities [Fudenberg, Levine and Tirole (1997)], and the possibility to form a "bloc" with other small economies in order to reduce its asymmetry during the negotiation process [Schiff (1996)]. At last, Section VII summarizes the main conclusions of this paper.

\section{FREE TRADE AREA OF AMERICAS: STYLISED FACTS}

Since the launch of the "Initiative for the Americas" in 1990, thirty-four countries have been negotiating the creation of the Free Trade Area of Americas (FTAA), which has been recognised as an example of New Regionalism defined by Ethier (1998). Although this paper is solely focused on trade liberalisation, the FTAA is organized in nine negotiation groups (namely: market access, agriculture, government procurement, safeguards, investments, services, compensatory and antidumping rules, competition policy, and intellectual property rules).

The sequential political game between two asymmetric economies developed in this paper is just an abstraction of real negotiation process between thirty four countries for the creation of the Free Trade Area of Americas. Nevertheless, this bilateral game structure reflects the concentration of political dispute by the United Sates and Brazil. On one hand, the United States accounts for almost $80 \%$ of American continent GDP and, therefore, naturally assumes the condition of Stackelberg leader. On the other hand, the condition of Stackelberg follower assumed by Brazil - the second larger economy of the American continent, with $6.4 \%$ of total GDP - is mainly motivated by Brazilian leadership among Latin American countries and by the clear alignment of Canadian and Mexican position with the United States. 
Table 1: Asymmetric distribution of GDP among FTAA members

\begin{tabular}{lcccr}
\hline Countries / Regional Blocs & Agriculture & Industry & Services & \multicolumn{1}{c}{ Total } \\
\hline South America & (\%GDP) & (\%GDP) & (\%GDP) & (US\$ billions) \\
\hline Mercosur & 7,9 & 30,7 & 61,4 & $1.406,31$ \\
\hline Brazil & 7,6 & 29,9 & 62,5 & $1.063,22$ \\
\hline Argentina & 8,6 & 30,6 & 60,8 & 751,50 \\
\hline Chile & 4,6 & 28,2 & 67,1 & 283,17 \\
\hline Central America & 8,4 & 34,2 & 57,4 & 67,47 \\
\hline NAFTA & 13,9 & 27,9 & 58,2 & 97,39 \\
\hline Mexico &.. &.. &.. & $10.270,73$ \\
\hline Canada & 5,0 & 28,2 & 66,8 & 483,74 \\
\hline United States &.. &.. &.. & 634,90 \\
\hline Total &.. &.. &.. & $9.152,10$ \\
\hline
\end{tabular}

Source: World Bank (2001), data of 1999

As regards the political dispute between the United States and Brazil, the asymmetric political game developed in this paper simply reflects economical and bilateral trade asymmetries between these two economies. Specifically, while the United States represents $24 \%$ of total Brazilian imports, Brazilian exports are just equivalent to $1 \%$ of total North-American imports.

Table 2: Bilateral trade between the United States and Brazil

\begin{tabular}{lccc}
\hline Imports Brazil & \multicolumn{3}{l}{ Imports USA } \\
\hline Total & \% USA & Total & \% Brazil \\
\hline 100.00 & 24.41 & 100.00 & 1.11 \\
\hline US\$ 59,73 billions & & US\$ 870,43 billions \\
\hline
\end{tabular}

Source: Funcex (1999)

The North-American tariff structure against Brazilian exports is characterized by low average tariffs and high tariff peaks for specific products, such as orange juice, nuts and tobacco. Furthermore, considering the whole bilateral trade, the Brazilian average tariff is higher than the North-American one. Nevertheless, considering only the main fifteen products imported by each country, tariff protectionism in the United States is higher than in Brazil. 
Table 3: Bilateral import tariffs in the fifteen main products

\begin{tabular}{lc}
\hline Country & Ad-valorem tariff \\
\hline Brazil & $14,3 \%$ \\
\hline United States & $45,6 \%$ \\
\hline
\end{tabular}

Sources: BRAZILIAN EMBASSY (2001) and USTR (2001)

Naturally, despite import tariffs and tariff peaks, bilateral trade between the United States and Brazil is also characterized by non-tariff barriers, including compensatory rights and antidumping rights for non-tariff barriers.

\section{ANALYTICAL FRAMEWORK}

Based on Grossman and Helpman (1995), both economies have similar characteristics regarding the strategies and the welfare functions of the average voter, lobby groups and government.

Each economy has a voting population of unitary size, producing and trading many goods, all the international prices of which are also normalized to 1 . There is a numéraire good 0 that is untaxed and $n$ other goods. Thus, individual preferences, per capita demands and individual surplus are, respectively, given by:

(1) $u(c)=c_{0}+\sum_{i=1}^{n} u_{i}\left(c_{i}\right), u^{\prime}()>0,. u^{\prime \prime}()<0$,

(2) $D_{i}\left(q_{i}\right), i=1, \ldots, n$ and $y-\sum_{i=1}^{n} D_{i}\left(q_{i}\right), i=0$, where $q_{i}$ is the domestic consumer price of good $i$ and

(3) $S_{i}\left(q_{i}\right)=u_{i}\left[D_{i}\left(q_{i}\right)\right]-q_{i} \cdot D_{i}\left(q_{i}\right)$

Furthermore, the production of the good 0 uses only one unit of labour per unit of output, while each other good is produced with constant returns to scale by labour and a sector-specific factor. Since competitive wages are set to 1 in equilibrium, aggregate supply is given by:

(4) $X_{i}\left(p_{i}\right)=\pi^{\prime}\left(p_{i}\right)>0$, where $p_{i}$ is the domestic producer price of the good $i$

Assuming that the ownership of the specific factors is highly concentrated in the population, the owners of a particular specific factor of sector $i$ have a common interest and, hence, form a special-interest group which takes political action in order to maximize joint welfare. Then, taking into account that government can either set a free-trade agreement or maintain the status quo, these various lobby 
groups offer financial contributions to politicians, hoping to influence the incumbent government's trade policy.

The Government values these financial contributions from lobby groups (C), but it may also care about the welfare of the average voter (W). The government's sensitivity to average voter's welfare relative to lobby contributions is given by parameter $a$. Thus, government's objective function is linearly given by:

(5) $G \equiv \sum_{i} C_{i}+a W$

Consequently, aggregate welfare of voters is given by:

(6) $W \equiv \sum_{i=1}^{n} S_{i}\left(q_{i}\right)+L+\sum_{i=1}^{n} \pi_{i}\left(p_{i}\right)+\sum_{i=1}^{n}\left(\tau_{i}-1\right) M_{i}$, where $\tau_{i}$ represents the tariff

over good $I, L$ represents labour income and $M$ represents lump-sum of the total import tariff revenue from the government

Since lobby groups capture a negligible fraction of consumer surplus and receive only an insignificant fraction of the rebated tariff revenue, their objective function can be closely approximated by their net profit of political contribution $\pi_{\mathrm{i}}\left(\mathrm{p}_{\mathrm{i}}\right)-\mathrm{C}_{\mathrm{i}}$. Then, $\pi_{\mathrm{i}}^{\mathrm{N}}$ and $\pi_{\mathrm{i}}^{\mathrm{F}}$, respectively, represent gross industry profits in the status quo and under a preferential trade agreement.

The impact of preferential trade agreements (PTA) over the welfare of lobby groups and average voters, directly depends of ex-ante protectionist structure and factors endowment. As regards to average voters, the traditional Viner (1950) analysis of trade creation and trade diversion effects remains valid: if most of goods are previously exported to the partner economy, there is welfare enhance; if most goods are previously imported from the partner economy, the welfare impact is ambiguous depending on the trade creation and trade diversion effects. Alternatively, as shown in Grossman and Helpman (1995), lobby groups of export sectors never lose and may gain under the preferential trade agreement, while lobby groups of import sectors never gain and sometimes even lose. Therefore, producers that export to their partner under PTA are a potential source of political support for an agreement, while producers that import from their partners under PTA represent a potential resistance.

\section{POLITICAL GAME: UNILATERAL STANCES}

Following Grossman and Helpman (1995) methodology, this first stage of the sequential political game focuses on political interactions in a single economy, which determine the nation's unilateral stance, that is, the optimal government responses to a balanced behavior by country's lobby groups, which forms the basis for the bilateral negotiations between two economies for the preferential trade agreement.

In this context, financial contributions of lobby groups may assume values 
$\mathrm{C}_{\mathrm{iN}}$ for the maintenance of the status quo or $\mathrm{C}_{\mathrm{iF}}$ for the preferential trade agreement.

The government will prefer the PTA if, and only if:

(7) $\sum_{i} C_{i F}+a W_{F} \geq \sum_{i} C_{i N}+a W_{N}$, where $\mathrm{W}_{\mathrm{R}}$ is the aggregate welfare under

regime $\mathrm{R}=\mathrm{N}, \mathrm{F}$

Basically, there are two generic types of unilateral stances: unpressured and pressured. An unpressured unilateral stance means that government takes the chosen regime despite financial contributions from supportive lobby groups. On the other hand, a pressured unilateral stance is one that government partly takes in response to financial contributions of lobby groups supporting this regime. Specifically, unpressured and pressured unilateral stances are, respectively, given by [see Results 1 and 2 in Grossman and Helpman (1995)]:

(8) $a\left(W_{R}-W_{\widetilde{R}}\right) \geq \max \left[0, \max _{i}\left(\pi_{i \widetilde{R}}-\pi_{i R}\right)\right]$, where $\widetilde{R}$ is the alternative regime to $R$.

(9) $\sum_{i^{\pi_{i R}}}+a W_{R} \geq \sum_{i^{\pi_{i}}}+a W_{\widetilde{R}}$

In cases where the unpressured and pressured stances differ, according to the notion of coalition-proof equilibrium ${ }^{4}$, the unpressured stance does not survive as equilibrium, since a coalition of lobby groups upsets the unpressured stance by minimal coordination of their political activities. This refinement of Nash $(1950,1953)$ equilibrium states that all coalition-proof equilibria select an action that maximizes the joint welfare of the lobby groups and politicians [see Result 3 in Grossman and Helpman (1995)].

However, since it is not possible for governments to exclude sensitive sectors from the trade liberalisation, the PTA will only be feasible if both unilateral stances are identical. Therefore, the possibility to exclude a few sensitivity sectors or to allow for some extended period of adjustment, definitely enhances the political feasibility of a preferential trade agreement.

In this new context, governments may choose status quo $(\mathrm{R}=\mathrm{N})$ or the preferential trade agreement $(\mathrm{R}=\mathrm{F})$ with a set of excluded sectors (eventually empty), maximizing its welfare function G. ${ }^{5}$ Now, each lobby group $i$ defines its financial contribution $C_{i} N, C_{i} \Omega$ and $C_{i} I$, respectively, related to the maintenance

\footnotetext{
${ }^{4}$ See Bernheim and Whinston (1987) and Bernheim et al (1987).

${ }^{5}$ In opposition to Grossman and Helpman (1995), this model does not allow ad infinitum exclusion of sensitive sectors from the preferential trade agreement. Specifically, according to negotiating principles of FTAA, all tariffs must be eliminated until 2020, allowing just an adjustment period until 2015 for those sectors extremely sensitive to foreign competition. Thus, as regards welfare effects of a PTA, FTAA is less favorable to lobby groups than the model of Grossman and Helpman (1995), reducing even more the probability of coalition-proof equilibrium for the implementation of FTAA.
} 
of status quo; to the PTA with the exclusion of sector $i$ and to the PTA with the inclusion of sector $i$.

Naturally, the exclusion of sensitive sectors from preferential trade agreement obeys an exclusion rule given by $\int_{i \in \Omega} T_{i} d i \leq T$, where $\Omega$ represents the set of excluded sectors, $\mathrm{T}_{\mathrm{i}}$ is the size of sector $i$ and $T$ is the exogenous limit imposed by the constraint. Besides, classify sectors so that $i \in[0, n]$ and $g_{i}=\left[\left(\Delta \Pi_{i}+\alpha \Delta W_{i}\right) / T_{i}\right]$, assigning the label $i_{0}$ to the sector with the lowest in the dex such as $g_{i}=0$, where $g_{i}$ represents the aggregate welfare of lobby groups and average voters divided by the size of the sector.

Thus, for any sector in set $\Omega(\mathrm{T})$, the joint gain to the government and lobby groups from liberalizing bilateral trade in good $i$ must be more negative than for any other sector not included in set $\Omega(\mathrm{T}) .{ }^{6}$ In this context, there are coalitionproof equilibrium and unilateral stance favorable to preferential trade agreement if, and only if:

$$
\begin{aligned}
& \text { (10) } \int_{i \in \Omega(T)}\left(\prod_{i N}+a W_{i N}\right) d i+\int_{i \notin \Omega(T)}\left(\prod_{i F}+a W_{i F}\right) d i \geq \int_{i}\left(\prod_{i N}+a W_{i N}\right) d i \\
& \text { (11) } \int_{i \in \Omega(T)}\left(a W_{i N}\right) d i+\int_{i \notin \Omega(T)}\left(a W_{i F}\right) d i+C \geq \int_{i}\left(a W_{i N}\right) d i \\
& \text { where } C=\int_{i \in \Omega(T)} \max \left[0, a\left(W_{i F}-W_{i N}\right)+\max _{j \notin \Omega(T)}\left(-T_{i} g_{i}\right)\right] d i
\end{aligned}
$$

In the coalition-proof equilibrium, each lobby group offers the same amount for the status quo and for the inclusion in set $\Omega(\mathrm{T})$, all sectors $\mathrm{j} \notin \Omega(\mathrm{T})$ offer for the exclusion the same amount they expect to lose from liberalizing their bilateral trade, and, finally, all sectors $i \in \Omega(\mathrm{T})$ offer for the exclusion at most the same amount they expect to gain from not being included in the preferential trade agreement [see results 4 and 5 in Grossman and Helpman (1995)].

Certainly, the ability to exclude some sensitive sectors from liberalisation of bilateral trade can save a preferential trade agreement that, otherwise, would not be politically viable due to the resistance of producers related to the economy's import sector.

In the following section, the political viability and the format of the preferential trade agreement are defined as the outcome of negotiating process between the larger economy leader of the Stackelberg model and the small economy following Stackelberg.

\footnotetext{
${ }^{6}$ See definition 2 of Grossman and Helpman (1995).
} 


\section{POLITICAL GAME: INTERNATIONAL NEGOTIATION}

Contrasting to the Nash bargaining game between two symmetric small economies developed by Grossman and Helpman (1995), the political and economical incentives to FTAA are analyzed through a Stackelberg game, in which the negotiation power of the small economy under influence of outside opportunities and the formation of blocs with other small economies is particularly focused. These are the main contributions of this paper for the political economy analysis of preferential trade agreements.

Given both unilateral stances previously defined at the first stage, this second part of the sequential political game focuses on the Stackelberg negotiation process between the larger and the smaller economies regarding the political feasibility and the format of the preferential trade agreement. Which sectors will be granted exclusions in an equilibrium agreement? In order to answer that question, Grossman and Helpman (1995) have developed a Nash bargaining model designed to maximize a geometric weighted average of the surpluses of both governments, in which $\alpha_{i}=0$ for sectors $i$ included in preferential trade agreement ( $i(E I)$ and $a_{i}=1$ for sectors $i$ excluded of PTA ( $\left.i \in E W\right)$. As a result, the bargaining process excludes all sectors $i \in\left[0, i^{*}\right]$. Here, the same welfare function is maximized by both economies:

$$
\max _{\alpha_{i}}: \Phi=\log \left\{\int_{i}\left[\left(1-\alpha_{i}\right)\left(a^{J} W_{i F}^{J}+C_{i l}^{J}\right)+\alpha_{i}\left(a^{J} W_{i N}^{J}+C_{i \Omega}^{J}\right)\right] d i-\int_{i}\left(a^{J} W_{i N}^{J}+C_{i N}^{J}\right) d i\right\}-\lambda\left[\int_{i} \alpha_{i} T_{i} d i-T\right]
$$

Naturally, given the significant asymmetry between the larger economy and the smaller one, the bargaining process is not feasible anymore, being replaced by a non-cooperative Stackelberg game. Henceforth, the large economy becomes the Stackelberg leader and maximizes its gain in comparison to the Nash bargaining equilibrium. Nevertheless, since the small economy can always choose the status $q u o$ instead of the preferential trade agreement, the large economy should carefully define its preferred format of PTA in order to not transform the agreement unattractive to the small economy.

Result 1: There is a coalition-proof equilibrium for the small economy in the non-cooperative Stackelberg game favorable to the preferential trade agreement if, and only if:

$$
\int_{i}\left[\left(1-\alpha_{i}\right)\left(a^{J} W_{i F}^{J}+C_{i l}^{J}\right)+\alpha_{i}\left(a^{J} W_{i N}^{J}+C_{i \Omega}^{J}\right)\right] d i-\int_{i}\left(a^{J} W_{i N}^{J}+C_{i N}^{J}\right) d i=0 \text { for } J=B
$$

with the exclusion of sectors $i \in\left[0, i^{* *}\right]$, where $i^{* *} \geq 0$.

Proof: According to Result 1, in Stackelberg equilibrium, the small economy will be indifferent between status quo (second integral on the left hand) and the PTA with the exclusion of sectors $i \in\left[0, i^{* *}\right.$ ] (first integral on the left hand). This is the natural outcome for a Stackelberg follower. Thus, if the gains due to the PTA are superior to the gains in status quo, the large economy can modify the set of excluded sectors in order to enhance its gains without turning the PTA 
unattractive to the small economy. By contrast, if the gains due to the PTA are inferior to the gains in status quo, the small economy can always choose the maintenance of the status quo. Therefore, the preferential trade agreement is a coalition-proof equilibrium for the small economy if, and only if, the small economy is exactly indifferent between the status quo and the preferential trade agreement.

Thus, the large economy defines the set of excluded sectors $i \in\left[0, i^{* *}\right]$ politically viable, maximizing its welfare given the reaction function of the small economy. Besides, since the exclusion of large economy industries sensitive to foreign competition reduces the welfare of exporting industries in the small economy, the small economy has a decreasing reaction function. Consequently, the leader of Stackelberg payoff is superior to the Nash bargaining payoff.

Result 2: There is a coalition-proof equilibrium for the small economy in the non-cooperative Stackelberg game favorable to the preferential trade agreement if, and only if, the payoff of the Stackelberg leader is superior to the Nash bargaining payoff.

Proof: According to Result 2, as regards the large economy, its gains due to the preferential trade agreement with the exclusion of sectors $i \in[0, i * *]$ are superior to gains under Nash bargaining equilibrium with the exclusion of sectors $i \in\left[0, i^{*}\right]$ developed by Grossman and Helpman (1995). By contrast, if Result 2 is not valid, the large economy can always abandon the Stackelberg leadership and play a bargaining game. See also Balboa et al. (2001).

Therefore, the economical asymmetry between the large and the small economy is directly reflected in their payoff matrix due to the preferential trade agreement with the politically viable set of excluded sectors $i \in\left[0, i^{* *}\right]$. The large economy maximizes its welfare as a Stackelberg leader, while the small economy becomes exactly indifferent between the status quo and the PTA.

\section{BARGAINING POWER OF THE SMALL ECONOMY}

According to the coalition-proof Stackelberg equilibrium, the preferential trade agreement is feasible if, and only if, the large economy maximizes its gains with the politically viable set of excluded sectors $i \in\left[0, i^{* *}\right]$, and the small economy is exactly indifferent between the bilateral liberalisation process and the status quo.

In this section, two alternative modifications in the original game structure are introduced in order to enhance the bargaining power of the small economy, which will be able to exclude more industries sensitive to foreign competition from the bilateral trade liberalisation. On the one hand, based on the incomplete

${ }^{7}$ See Fudenberg and Tirole (2000), p. 75. 
information bargaining model, with outside opportunities developed by Fudenberg et al. (1987), the small economy can not only negotiate with the large economy but also choose to interrupt current bargaining process and, then, bargain with a third economy for a new preferential trade agreement. On the other hand, as suggested by Schiff (1996) and Pereira (1997), the small economy may choose to bargain in "blocs" with other small economies for reducing its asymmetry in relation to the large economy.

As regards outside opportunities, the small economy may choose to maintain the status quo, to establish a preferential trade agreement with the large economy or, at last, to interrupt current negotiations with the large economy and bargain with a third economy for a new bilateral trade agreement. In this new context, its decision is mainly influenced by the existence of delay costs ${ }^{8}$ and by the international strategy of the third economy. On the one hand, the existence of delay costs turns the interruption of current negotiations less attractive to the small economy. On the other hand, once current negotiations are interrupted in favour of outside opportunity, the bargaining power of the small economy is naturally influenced by its relative size in comparison to the third economy. It follows that the existence of outside opportunities potentially enhances the bargaining power of the small economy regarding the large economy.

Result 3: (without delay costs) Given the existence of outside opportunities to the small economy, there is a coalition-proof equilibrium favorable to the preferential trade agreement with the large economy if, and only if:

$$
\begin{aligned}
& \int_{i}\left[\left(1-\alpha_{i}\right)\left(a^{A B} W_{i F}^{A B}+C_{i l}^{A B}\right)+\alpha_{i}\left(a^{A B} W_{i N}^{A B}+C_{i S}^{A B}\right)\right] d i-\int_{i}\left(a^{A B} W_{i N}^{A B}+C_{i N}^{A B}\right) d i=\Psi \\
& \Psi \geq \max \left\{0,\left[\int_{i}\left[\left(1-\alpha_{i}\right)\left(a^{C B} W_{i F}^{C B}+C_{i l}^{C B}\right)+\alpha_{i}\left(a^{C B} W_{i N}^{C B}+C_{i S}^{C B}\right)\right] d i-\int_{i}\left(a^{C B} W_{i N}^{C B}+C_{i N}^{C B}\right) d i\right]\right\}
\end{aligned}
$$

With the exclusion of sectors $\mathrm{i} \in\left[0, \mathrm{i}^{\delta}\right], \mathrm{i}^{\delta} \geq 0$, where $\mathrm{AB}$ refers to the $\mathrm{PTA}$ between the small economy and the large economy, and $\mathrm{CB}$ refers to the PTA between the small economy and the third economy.

Proof: Result 3 establishes that the welfare of small economy under preferential trade agreement $\mathrm{AB}$ is weakly inferior to the preferential trade agreement $\mathrm{CB}$ and strictly superior to the preferential trade agreement given by the equation (13). In contrast, assuming that $\Psi<0$, the small economy prefers the status quo or the outside opportunity. Alternatively, the small economy prefers the outside opportunity if:

$$
\text { if } \Psi<\int_{i}\left[\left(1-\alpha_{i}\right)\left(a^{C B} W_{i F}^{C B}+C_{i l}^{C B}\right)+\alpha_{i}\left(a^{C B} W_{i N}^{C B}+C_{i \Omega}^{C B}\right)\right] d i-\int_{i}\left(a^{C B} W_{i N}^{C B}+C_{i N}^{C B}\right) d i
$$

\footnotetext{
${ }^{8}$ See also Admati and Perry (1987).
} 
Finally, if $\int_{i}\left[\left(1-\alpha_{i}\right)\left(a^{C B} W_{i F}^{C B}+C_{i l}^{C B}\right)+\alpha_{i}\left(a^{C B} W_{i N}^{C B}+C_{i \Omega}^{C B}\right)\right] d i-\int_{i}\left(a^{C B} W_{i N}^{C B}+C_{i N}^{C B}\right) d i=0$, then the small economy is indifferent between status quo and preferential trade agreement, whatever the opponent is.

Thus, given the inexistence of delay costs, the large economy (previously the Stackelberg leader) should offer to the small one strictly positive gains with the PTA (and, hence, superior to Stackelberg equilibrium welfare), and, at least, identical to potential welfare gains eventually obtained in the PTA with the third economy. In this new context, the new set of excluded sectors $i \in[0, i \delta]$ implies higher welfare gains to the small economy in comparison to the original Stackelberg equilibrium set of excluded sectors $i \in[0, i * *$.

The presence of delay costs obviously reduces potential welfare gains to the small economy, since the interruption of current negotiations becomes less attractive. Nevertheless, the small economy is still able to enhance its in relation power relative to the Stackelberg game.

Result 4: (with delay costs) Given the existence of outside opportunities to the small economy, there is a coalition-proof equilibrium favorable to the preferential trade agreement with the large economy if, and only if:

and

(16) $\int_{i}\left[\left(1-\alpha_{i}\right)\left(a^{A B} W_{i F}^{A B}+C_{i l}^{A B}\right)+\alpha_{i}\left(a^{A B} W_{i N}^{A B}+C_{i \Omega}^{A B}\right)\right] d i-\int_{i}\left(a^{A B} W_{i N}^{A B}+C_{i N}^{A B}\right) d i=\Psi$

$$
\Psi \geq \max \left\{0,\left[\int_{i}\left[\left(1-\alpha_{i}\right)\left(a^{C B} W_{i F}^{C B}+C_{i l}^{C B}\right)+\alpha_{i}\left(a^{C B} W_{i N}^{C B}+C_{i \Omega}^{C B}\right)\right] d i-\int_{i}\left(a^{C B} W_{i N}^{C B}+C_{i N}^{C B}\right)\right]-D\right\}
$$

with the exclusion of sectors $\mathrm{i} \in\left[0, \mathrm{i}^{\theta}\right], \mathrm{i}^{\theta} \geq 0$, where $\mathrm{D}$ represents the delay costs involved in the interruption of current negotiation and the start of a new bargaining process.

Proof: Result 4 states that, discounting delay costs, welfare gains obtained by the small economy under preferential trade agreement $\mathrm{AB}$ are weakly superior to welfare gains due to the preferential trade agreement $\mathrm{CB}$, and strictly superior to welfare in equation (13). In contrast, assuming $\Psi<0$, the small economy prefers status quo or the PTA with the third economy, since welfare gains are higher than delay costs D. On the other hand, even in the presence of delay costs, the small economy prefers the outside opportunity if:

(18) $\Psi<\int_{i}\left[\left(1-\alpha_{i}\right)\left(a^{C B} W_{i F}^{C B}+C_{i l}^{C B}\right)+\alpha_{i}\left(a^{C B} W_{i N}^{C B}+C_{i \Omega}^{C B}\right)\right] d i-\int_{i}\left(a^{C B} W_{i N}^{C B}+C_{i N}^{C B}\right) d i-D$

At last, if $\int\left[\left(1-\alpha_{i}\right)\left(a^{C B} W_{i F}^{C B}+C_{i l}^{C B}\right)+\alpha_{i}\left(a^{C B} W_{i N}^{C B}+C_{i \Omega}^{C B}\right)\right] d i-\int\left(a^{C B} W_{i N}^{C B}+C_{i N}^{C B}\right) d i=0$ then the small economy never prefers the outside opportunity.

Thus, given the presence of delay costs, the interruption of current negotiations with the large economy is less attractive to the small economy. Nevertheless, the 
set of excluded sectors $i \in\left[0, i^{\theta}\right]$ is still weakly preferred to Stackelberg equilibrium set of excluded sectors $i \in\left[0, i^{* *}\right]$.

Therefore, the existence of outside opportunities to the small economy enhances its bargaining power regarding the large economy in comparison to the Stackelberg game. It follows that current trade negotiation between Brazil and the European Union enhances Brazilian bargaining power in relation to the United States for the creation of the Free Trade Area of Americas.

Alternatively, according to Schiff (1996), the small economy may also obtain better benefits from the preferential trade agreement by negotiating as a "regional bloc." In this new context, the small economy enhances its bargaining power in relation to the large economy by defining a common bargaining strategy with other small economies, since the set of excluded sectors is now more favorable in comparison to the original Stackelberg equilibrium set of excluded sectors $\Omega(T)$.

Thus, suppose a large economy involved in bargaining processes with several small economies for the creation of preferential trade agreements. If all small economies decide to negotiate separately with the large economy, each small economy becomes indifferent between status quo and the preferential trade agreement, while the large economy obtains the Stackelberg leader payoff in all bargaining processes.

Result 5: Suppose a large economy involved in isolated bargaining processes with several small economies $\mathrm{j}=1, \ldots, \mathrm{N}$ for the creation of preferential trade agreements. Then, if small economies decide to negotiate separately, the Stackelberg coalition-proof equilibrium prevails with the exclusion of sectors $\mathrm{i}_{\mathrm{j}} \in\left[0, \mathrm{i}_{\mathrm{j}} * *\right]$, where $\mathrm{i}_{\mathrm{j}} * *$ corresponds to the cut-off value in each small economy. Therefore, the large economy obtains the Stackelberg leader payoff, while each small economy becomes exactly indifferent between status quo and the preferential trade agreement.

Proof: In the absence of coalition between small economies, the large economy becomes the natural Stackelberg leader in all bargaining processes and Result 1 is valid.

On the other hand, each small economy may decide to constitute a coalition with other small economies in order to bargain with the large economy, reducing the asymmetry as regards the large economy and obtaining higher benefits with the PTA in comparison to the Stackelberg follower payoff.

Result 6: Suppose a large economy involved in isolated bargaining processes with several small economies $\mathrm{j}=1, \ldots, \mathrm{N}$ for the creation of preferential trade agreements. Then, if small economies decide to constitute a coalition, the politically viable set of excluded sectors under the PTA will be $\mathrm{i} \in\left[0, \mathrm{i}^{\tau}\right]$, where $\mathrm{i}^{\tau}$ is defined through the bargaining process with the large economy. In this case, the large economy obtains a payoff weakly inferior to the Stackelberg leader payoff, while the coalition of small economies obtains gains strictly superior to the Stackelberg follower payoff.

Proof: If preferential trade agreement benefits obtained by small economies as a coalition are inferior to the Stackelberg follower payoff, these economies 
would not constitute the coalition at first. Alternatively, if these benefits are exactly equal to the Stackelberg follower payoff, small economies would not be interested in negotiating as a coalition due to eventual unilateral stances conflict. Actually, although lobby groups are able to influence national trade policy, they cannot influence the unilateral stance for the coalition of small economies. It follows that a coalition between small economies may not be a coalition-proof equilibrium.

In particular, Brazilian government decided to form a coalition with other members of Mercosur in order to reduce its asymmetry in relation to the United States under negotiation process for the creation of the Free Trade Area of Americas.

\section{CONCLUSION}

This paper analyses the political economy of a preferential trade agreement based on a sequential non-cooperative game between two asymmetric economies, in which both unilateral stances reflect the relative political power of lobby groups representing industry special interests and also the extent of government's concern for the plight of the average voter and, then, international bargaining defines the political feasibility of the preferential trade agreement.

The initial stage of this political game is entirely based on Grossman and Helpman (1995) model, in which coalition-proof unilateral stances reflect the optimal government responses to the equilibrium behavior by country's lobby groups. Then, in contrast to the Nash bargaining game developed by Grossman and Helpman (1995), the political and economical incentives to the special case of FTAA are analysed through a Stackelberg game, in which the large economy maximizes its welfare as a Stackelberg leader, while the small economy becomes indifferent between the status quo and the PTA.

Two alternative modifications in the original game structure are introduced in order to enhance the bargaining power of the small economy, which will be able to exclude more industries sensitive to foreign competition from the bilateral trade liberalisation. On one hand, based on Fudenberg et al. (1987), the small economy can not only negotiate with the large economy but also choose to interrupt current bargaining process and, then, bargain with a third economy for a new preferential trade agreement. On the other hand, as suggested by Schiff (1996), the small economy may choose to constitute a coalition with other small economies for reducing its asymmetry relative to the large economy.

Concluding, the mathematical model developed in this paper provides important reflections about the low probability of the creation of free trade agreements between two asymmetric economies. In this context, the unequal bargaining power of the large economy eventually eliminates minimum gains for the small economy, mitigating the FTA. This paper argues that the model can describe the outcomes of current FTAA negotiations, by simplifying the multi- 
negotiation into a bilateral political game. One possible future development could be the generalisation of this bilateral model for a multi-country political negotiation.

\section{REFERENCES}

ADMATI, A. R. and PERRY, M. (1987), Strategic Delay in Bargaining, In: Review of Economic Studies, 54: 345-64.

BALBOA, O. I.; DAUGHETY, A. F. and REINGANUM, J. F. (2001), Market Structure and the Demand for Free Trade, Vanderbilt University, working paper.

BALDWIN, R. E. and VENABLES, A. J. (1995), Regional economic integration. In: Grossman, G. and Rogoff, K. (Ed.), Handbook of International Economics, vol. 3, North-Holland, Amsterdam.

BERNHEIM, B. D. and WHINSTON, M. D. (1986), Menu Auctions, Resource Allocation and Economic Influence, In:Quarterly Journal of Economics, 101 (1): 1-31.

BERNHEIM, B. D. and WHINSTON, M. D. (1987), Coalition-Proof Nash Equilibria II: Applications, In: Journal of Economic Theory, 42: 13-29.

BERNHEIM, B. D., PELEG, B. and WHINSTON, M. D. (1987), Coalition-Proof Nash Equilibria I: Concepts. In: Journal of Economic Theory, 42: 1-12.

BHAGWATI, J. and PANAGARIYA, A. (1996), The theory of preferential trade agreements: historical evolution and current trends. In: American Economic Review, 86: 82-87.

BHAGWATI, J. (1971), Trade-Diverting Customs Unions and Welfare-Improvement: a Clarification. In:Economic Journal, (September): 580-87.

BRAZILIAN EMBASSY (2001), U.S. Barriers to Brazilian Goods and Services, Washington D.C.

DIXIT, A. and NORMAN, V. D. (1980), The Theory of International Trade, Cambridge University Press.

ETHIER, W. E. (1998), Regionalism in a multilateral world, Journal of Political Economy, 106(6):1214-1245.

FTAA (2001), Free Trade Area of Americas, draft texts, www.ftaa-alca.org

FUDENBERG, D.; LEVINE, D. and TIROLE, J. (1987), Incomplete Information Bargaining with Outside Opportunities. In: Quarterly Journal of Economics, p. 37-50.

FUDENBERG, D. and TIROLE, J. (2000), Game Theory, The MIT Press.

FUNCEX (1999), Barreiras comerciais às exportações brasileiras 1999, SECEX.

FREUND, C. (2000), Multilaterism and the endogenous formation of preferential trade agreements. In: Journal of International Economics, 52: 359-376.

GROSSMAN, G. M. and HELPMAN, E. (1994), Protection for sale, American Economic Review, 84: 833-850.

GROSSMAN, G. M. and HELPMAN, E. (1995), The politics of free-trade agreements. In: American Economic Review, 85: 667-690.

HELPMAN, E. and KRUGMAN, P. (1991a), Trade Policy and Market Structure, The MIT Press. HELPMAN, E. and KRUGMAN, P. (1991b), Market Structure and Foreign Trade, The MIT Press. HELPMAN, E. (1995), Politics and Trade Policy, NBER, working paper 5309.

KRISHNA, P. (1998), Regionalism and multilaterism: a political economy approach. In: Quarterly Journal of Economics, 113: 227-251. 
KRUEGER, A. (1995), Free trade agreements versus customs unions, NBER, working paper 5084.

KRUEGER, A. (1999), Trade Creation and Trade Diversion under NAFTA, NBER, working paper 7429.

KRUGMAN, P. (1991), Is bilaterism bad? In: Helpman, E. and Razin, A. (Ed.), International Trade and Trade Policy, Cambridge: MIT Press,.

NASH, J. F. (1950), The bargaining problem. In: Econometrica, 18: 155-2.

NASH, J. F. (1953), Two-person cooperative games. In: Econometrica, 21: 128-40.

OBSTFELD, M. (1998), EMU: Ready or Not?, NBER, working paper 6682.

PEREIRA, L. V. (1997), Agenda de Integração Brasileira: uma avaliação preliminar. In:Revista de Conjuntura Econômica, ESPECIAL, May: p.26-31.

SCHIFF, M. (1996), Small is Beautiful: Preferential Trade Agreements and the Impact of Country Size, Market Share, Efficiency, and Trade Policy, World Bank, working paper 1668.

USTR (2001), U.S. Positions in the Free Trade Area of Americas, available at www.ustr.gov

VINER, J. (1950), The customs union issue, New York

WORLD BANK (2001), World Development Indicators, CD-ROM 